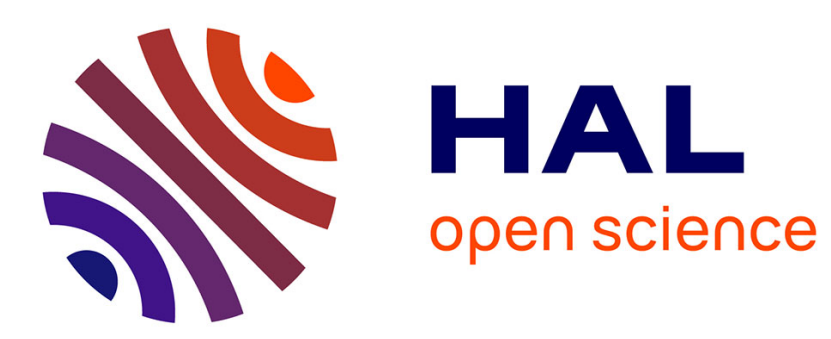

\title{
Copper-Cerium Oxide Catalysts for CO Oxidation: An EXAFS and XRD Study
}

W. Daniell, N. Lloyd, C. Bailey, P. Harrison

\section{To cite this version:}

W. Daniell, N. Lloyd, C. Bailey, P. Harrison. Copper-Cerium Oxide Catalysts for CO Oxidation: An EXAFS and XRD Study. Journal de Physique IV Proceedings, 1997, 7 (C2), pp.C2-963-C2-964. 10.1051/jp4:19972103 . jpa-00255160

\section{HAL Id: jpa-00255160 https://hal.science/jpa-00255160}

Submitted on 1 Jan 1997

HAL is a multi-disciplinary open access archive for the deposit and dissemination of scientific research documents, whether they are published or not. The documents may come from teaching and research institutions in France or abroad, or from public or private research centers.
L'archive ouverte pluridisciplinaire HAL, est destinée au dépôt et à la diffusion de documents scientifiques de niveau recherche, publiés ou non, émanant des établissements d'enseignement et de recherche français ou étrangers, des laboratoires publics ou privés. 


\title{
Copper-Cerium Oxide Catalysts for CO Oxidation: An EXAFS and XRD Study
}

\author{
W. Daniell, N.C. Lloyd, C. Bailey and P.G. Harrison
}

Department of Chemistry, University of Nottingham, University Park, Nottingham, NG7 2RD, UK

\begin{abstract}
Mixed copper-cerium oxides were prepared by two methods leading to different copper species in the as-prepared material. At the catalyst operating temperature $\left(300-400^{\circ} \mathrm{C}\right)$ and above, the same copper species was present irrespective of the preparation technique. A solid solution having the same fluorite structure as that of pure $\mathrm{CeO}_{2}$ was formed and remained stable after calcination to $1000^{\circ} \mathrm{C}$. At temperatures in excess of $600^{\circ} \mathrm{C}$ the formation of a CuO phase was also noticed. Catalytic activity of the mixed copper-cerium oxides for the oxidation of $\mathrm{CO}$ to $\mathrm{CO}_{2}$ proved very favourable even under $\mathrm{O}_{2}$ poor conditions. Activity decreasesd with increasing calcination temperature as the material sintered and lost surface area, and the copper species deactivated through formation of CuO. The importance of EXAFS as an analytical tool in ascertaining the nature of the copper species at the catalyst operating temperature was highlighted.
\end{abstract}

\section{INTRODUCTION}

Cerium (IV) oxide, ceria, is widely used as a support for current state-of-the-art Pt and Rh based automobile catalysts [1]. However, due to the ever increasing demand upon expensive PGMs, viable alternative non-noble metal catalysts are being sort. Ceria exhibits two features that make it a promising material for use as a support for such a redox catalyst. Firstly it has the ability to shift easily between $\mathrm{CeO}_{2}$ and $\mathrm{Ce}_{2} \mathrm{O}_{3}$ depending on whether it is present in an oxidizing or reducing atmosphere; and secondly, it contains numerous oxygen vacancies within its structure leading to high oxygen mobility [2]. Research into doping ceria with other metals such as $\mathrm{Hf}$ and $\mathrm{Zr}$ has already proved promising [3]. We describe here the preparation, characterization and testing of copper doped cerium oxides for use as automobile exhaust gas catalysts.

\section{EXPERIMENTAL}

Mixed copper-cerium oxides were prepared via two routes: impregnation and coprecipitation. Impregnation involved stirring cerium oxide powder in an aqueous solution of $\mathrm{Cu}\left(\mathrm{NO}_{3}\right)_{2} .6 \mathrm{H}_{2} \mathrm{O}$ of an appropriate concentration for 24 hours, followed by filtering and drying. Coprecipitation was achieved by adding ammonia dropwise to a vigorously stirred aqueous solution of $\mathrm{Ce}\left(\mathrm{NO}_{3}\right)_{3} \cdot 6 \mathrm{H}_{2} \mathrm{O}$ and $\mathrm{Cu}\left(\mathrm{NO}_{3}\right)_{2} \cdot 6 \mathrm{H}_{2} \mathrm{O}$ of the desired ratio. After precipitation the mixture was centrifuged, washed and dried for 24 hours at $100^{\circ} \mathrm{C}$. All samples were calcined for 18 hours at temperatures of 300,600 and $1000^{\circ} \mathrm{C}$.

The samples were characterized by surface area (BET) measurements, ESR, FTIR, powder XRD and EXAFS. Catalytic

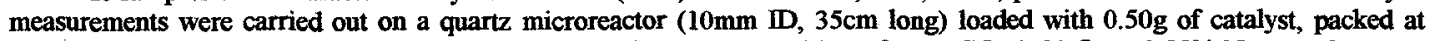

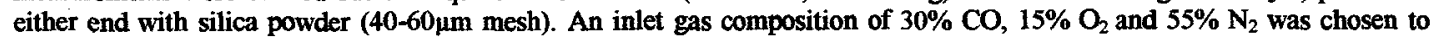
obtain stoichiometric oxidation. Both inlet and outlet gas compositions were monitored by FTIR.

\section{RESULTS AND DISCUSSION}

\subsection{X-Ray Diffraction analysis}

Powder XRD patterns were obtained of samples calcined at 600 and $1000^{\circ} \mathrm{C}$. The cubic pattern of ceria (fluorite structure) was most prominent, but a second phase of $\mathrm{CuO}$ was also discernable at both temperatures. A shifting of the ceria peaks to lower $2 \theta$ values indicated the formation of a solid solution. Analysis of the ceria pattern using the Dicvol'91 programme confirmed a distortion in the unit cell (dimensions changing from $\mathrm{A}=5.406$, volume $=158.04$ in the pure $\mathrm{CeO}_{2}$, to $\mathrm{A}=5.421$, volume $=159.30$ in the solid solution). Rietveld modelling confirmed the formation of a copper-ceria solid solution based on the ceria fluorite structure. Since the solid solution appeared stable even at $1000^{\circ} \mathrm{C}$, it seemed that the $\mathrm{CuO}$ phase was being formed from copper not incorporated into the ceria lattice.

Patterns at $1000^{\circ} \mathrm{C}$ were sharper indicating sintering and a more crystalline nature. From the half-height peak widths and the application of the Scherer equation, average crystallite sizes were ascertained $(67,357$ and $2871 \mathrm{~A}$ at 300 , 600 and $1000^{\circ} \mathrm{C}$ respectively). The trend towards larger crystallites and hence lower surface areas at increased temperatures was 
mirrored in the BET analysis. A BET surface area of $180 \mathrm{~m}^{2} / \mathrm{g}$ for an as-prepared coprecipitated sample, decreased to $106 \mathrm{~m}^{2} / \mathrm{g}$ upon calcination to $400^{\circ} \mathrm{C}$.

\subsection{EXAFS}

Extended $\mathrm{x}$-ray absorption fine structure spectroscopy was used to identify the nature of the active copper species present within the catalyst at each calcination temperature. For the impregnated samples, the copper appeared to be present in a hydrated surface species in the as-prepared state, and underwent incorporation into the ceria lattice with temperatures reaching $300^{\circ} \mathrm{C}$. After calcination at $600^{\circ} \mathrm{C}$, the formation of $\mathrm{CuO}$ was noticed, but this was not at the expense of copper within the ceria solid solution, which was still present after calcination to $1000^{\circ} \mathrm{C}$.

The low temperature copper aquo species was interpreted as being similar to that of $\mathrm{Cu}\left(\mathrm{H}_{2} \mathrm{O}\right)_{6}{ }^{2+}$, with the central copper cation in an octahedral complex. Data fitting using the Excurve'92 programme assigned first shell nearest neighbours as 4 oxygen atoms at a distance of $1.88 \mathrm{~A}$ (for the water molecules in square planar arrangement), and two oxygens at a distance of 1.93A (above and below the plane; accounting for a Jahn-Teller distortion). A similar species has been reported with copper doped tin oxide, the aquo species being bonded to the support surface via weak hydrogen bonds through the water molecules[4]. At $300^{\circ} \mathrm{C}$, with the copper present in the fluorite structure of the ceria lattice, fitting suggests copper sitting in a cerium ion site within the structure, in an octahedral arrangement with 8 oxygens. Data for samples calcined at higher temperatures still indicates the presence of the solid solution, but fits are poorer due to the formation of the CuO phase (indicated by XRD).

Coprecipitated samples differed from those formed by impregnation only in the as-prepared sample. Here the copper was already incorporated into the ceria lattice as part of the solid solution at the preparation stage. ESR spectroscopy, however, confirmed the presence of more than one copper species in this sample, being similar to the bulk and surface aquospecies obtained with tin oxide supports[4]. The appearance of a triplet signal in the sample calcined at $600^{\circ} \mathrm{C}$ was also noted, caused by the formation of copper-ion dimers in adjacent metal sites within the ceria lattice[5].

\subsection{Catalytic activity}

All samples were pretreated under a flow of air at $300^{\circ} \mathrm{C}$ for 2 hours before testing. Results are summarized in table 1. Catalytic activity increased with copper content but decreased with increasing calcination temperature. This can be attributed to loss of surface area and deactivation of the copper species present. The $20 \%$ loaded sample calcined at $300^{\circ} \mathrm{C}$ exhibited a light off temperature (the point at which conversion first occurs) of $25^{\circ} \mathrm{C}$, with total conversion occuring at $53^{\circ} \mathrm{C}$. Once activated the sample could operate at maximum capacity for over 24 hours at ambient temperature.

Table 1: conversion data for the complete oxidation of carbon monoxide

\begin{tabular}{llll}
\hline SAMPLE & CALCINATION & LIGHT-OFF & 100\% CONVERSION \\
& TEMPERATURE $/{ }^{\circ} \mathrm{C}$ & TEMPERATURE $\rho^{\circ} \mathrm{C}$ & \begin{tabular}{l} 
TEMPERATURE $/{ }^{\circ} \mathrm{C}$ \\
\hline
\end{tabular} \\
\hline & 300 & & 353 \\
$\mathrm{CeO}_{2}$ & 300 & 230 & 85 \\
$10 \mathrm{Cu} 90 \mathrm{Ce}$ oxide & 300 & 56 & $25^{*}$ \\
$20 \mathrm{Cu} 80 \mathrm{Ce}$ oxide & 600 & 25 & 82 \\
& 1000 & 75 & 282 \\
\hline
\end{tabular}

\section{CONCLUSION}

*once activated by heating to $53^{\circ} \mathrm{C}$

The incorporation of copper into the ceria lattice has a dramatic effect on its ability to oxidize $\mathrm{CO}_{\text {to }} \mathrm{CO}_{2}$. The formation of a solid solution occurs during coprecipitation, or upon heating to $300^{\circ} \mathrm{C}$ for samples made via impregnation. Catalytic activity is improved through the creation of oxygen vacancies within the fluorite structure which leads to increased oxygen mobility. Activity decreases with increasing calcination temperature due to loss of surface area and deactivation of the copper on forming $\mathrm{CuO}$. The solid solution is stable even after heating to $1000^{\circ} \mathrm{C}$.

\section{Acknowledgements}

The authors are grateful to the European Union (WD) and the EPSRC (NL, CB) for financial support, and to DRAL for the facilities at SRS Daresbury.

\section{References}

[1] Nunan J.G., Robota H.J., Cohn M.J., Bradley S.A., J.Catal 133 (1992) 309-324

[2] Sayle T.X.T., Parker S.C., Catlow C.R.A., J. Chem. Soc.,Chem. Commun. (1992) 977-978

[3] Zamar F., Trovarelli A., Leitenburg C., Dolcetti G., J. Chem. Soc., Chem. Commun. (1995) 965-966.

[4] Matar K., Zhao D., Goldfarb D., Azelee W., Daniell W., Harrison P.G., J. Phys. Chem., 99 (1995) $9966-9973$

[5] Abi-Aad E., Bennani A., Bonnelle J-P., Aboukais A., J. Chem. Soc. Faraday Trans., 9111 (1995) 99-104 